https://doi.org/10.5817/OS2018-4-4

\title{
Za profesorem Stanislavem Žažou
}

Uprostř̌ed letošního horkého léta, 5. srpna 2018, ve věku 89 let, opustil tiše naše řady a své nejbližší emeritní profesor Ústavu slavistiky Filozofické fakulty Masarykovy univerzity v Brně PhDr. Stanislav Žaža, CSc.

Poměřuje-li se $\mathrm{v}$ př́ípadě úmrtí významných členů akademické obce hodnota osobnosti ve vztahu k danému profesnímu prostředí mírou jejich nahraditelnosti, pak v př́padě Stanislava Žaži rozhodně není pouhou z piety k zesnulému užitou frází, že především česká rusistika (a brněnská tím spíš) utrpěla $v$ tomto případě ztrátu, kterou se už patrně nikdy plnohodnotně zacelit nepodaří. Obdivuhodná šíře odborných jazykovědných zájmů a rozsah i hloubka znalostí z oblasti jak slovanské, tak klasické filologie, tolik charakteristické pro před- i poválečnou generaci slavistů, vytvářely jak pro vědeckou práci, tak pro pedagogické působení Stanislava Žaži předpoklady, kterých se mnohým jeho následovníkům v potřebné míře nedostává. Zesnulý byl navíc obdařen nebývalou schopností, ba nutkavou potřebou účelně propojovat badatelskou teoretickou činnost (především $\mathrm{v}$ oblasti jazykovědné rusistiky) $\mathrm{s}$ bezprostředním pedagogickým působením na své studenty: bylo mu cizí suchopárné, rádoby hluboce sofistikované abstraktní teoretizování odtržené od popisu a analýzy konkrétních jazykových jevů a živého řečového materiálu. Při psaní odborných článků a př́ipravě konferenčních vystoupení měl vždy na paměti aplikovatelnost zjištěných poznatků při výuce a osvojování si ruštiny jako cizího jazyka. „K čemu to je?“ ptával se často nejen sám sebe, když přehližel názvy a anotace časopiseckých studií či sborníkových př́spěvků, z nichž pro přemíru cizojazyčných odborných termínů, sémantickou mlhu či syntaktickou vyumělkovanost nebylo zřejmé, o čem daný text pojednává. Bytostně nesnášel akademickou nabubřelost a pohrdání „nedostatečně poučeným“ čtenářem.

Ve výzkumné i pedagogické činnosti se Stanislav Žaža orientoval především na ruskou větnou skladbu, velmi dobře si však přitom uvědomoval neoddělitelnost a vzájemnou podmíněnost syntaktických jevů a sémantiky skladebných prvků jazyka, a toto povědomí pro něho bylo základním metodologickým principem ve vědě i výuce, současně $\mathrm{s}$ důsledně uplatňovaným komparativním př́istupem, který vnímal jako jediný smysluplný a efektivní způsob uvědomělého osvojování si cizího jazyka, čehož dokladem je mj. jeho habilitační spis Sémantická a syntaktická stránka konstrukcí se slovesem быmb // býti (1979). Jako školitel trval na tom, aby srovnávací metodu ve svých seminárních pracích a diplomových projektech důsledně uplatňovali také jeho studenti: „O ruštině si všechno a lépe napíší Rusové sami, my musíme ukazovat, v čem se ruština liší od češtiny a proč - to za nás nikdo neudělá“, říkával, když se některému z diplomantů nebo i začínajících mladých kolegů do srovnávacích studií př́liš nechtělo. 
Důkazem samozřejmé potřeby profesora Žaži předávat své vědomosti novým generacím rusistů je autorství či spoluautorství řady vysokoškolských učebních textů a príruček, $\mathrm{z}$ nichž na tomto místě připomínáme jen ty nejdůležitější: autorsky se podílel napr. na mimořádně ceněné a dodnes využívané Př́ruční mluvnice ruštiny pro Čechy. Díl II - Skladba z r. 1960, která se dočkala celkem trojího vydání (posledního v r. 1979), na vysokoškolské učebnici Орфография, пунктуащия и книжно-письменная речь русского языка (1979) i její zestručněné české verzi Př́ručka ruského pravopisu (1983), dále na učebnici Русский синтаксис в сопоставлении с чешским (1983), dvoudílném učebním textu Morfologie ruštiny I-II (1996 a 1997), a nakonec ve spolupráci s Helenou Flídrovu na skriptu Синтаксис русского языка в сопоставлении с чешским (2005, 2013); sám je pak autorem učebních textů Paradigmatika a akcentuace ruského slovesa I. Tř́dění sloves (1968, 1978, 1988), Paradigmatika a akcentuace ruského slovesa II. Př́zvuk slovesných tvarů (1991), Základy ruštiny pro filology v porovnání s češtinou (1992) a jeho přepracované verze Ruština a čeština $v$ porovnávacím pohledu (1999), kvalifikaci klasického filologa zužitkoval v učebních textech Latina pro studenty východoslovanských jazyků (200o) a Latina a řečtina $v$ slovní zásobě, gramatice a terminologii slovanských jazyků (2010).

Žánr nekrologu má své zákonitosti a předpokládá mimo jiné připomínku nejdůležitější faktických údajů z osobního a profesního života zesnulého. Věřím však, že mi čtenáři odpustí, když v tomto př́ípadě zcela výjimečně zneužiji postavení výkonného redaktora, využiji toho, že o profesoru Žažovi a jeho celoživotním díle bylo při př́ležitosti jeho životních jubileí už mnohokrát mnoho napsáno, a namísto nošení sov do Athén si dovolím uvést na tomto místě pro dokreslení lidského profilu mého nezapomenutelného učitele a později staršího kolegy a blízkého člověka několik krátkých osobních vzpomínek.

Vzpomínka první - studentská. Studoval jsem na brněnské filozofické fakultě na přelomu 70.-80. let minulého století a pamatuji si proto Stanislava Žažu krátce ještě jako odborného asistenta a následně docenta na tehdejší katedře ruského jazyka. Snažil jsem se být dobrým studentem, ale na zkoušku z ruské syntaxe jsem nepřišel připravený tak, jak bych si sám přál. Pan docent moji nejistotu vycítil, a ačkoliv ten den zkoušel už asi šestou hodinu, trpělivě mne promyšleně volenými otázkami vedl k tomu, že jsem nakonec dokázal jakž takž dát dohromady i to, co jsem nevěděl. Styděl jsem se za svůj výkon strašně, zvlášt́, když jsem od zkoušky nakonec odcházel s výbornou a s úsměvným ujištěním, že do státnic své i tak výborné znalosti určitě ještě vylepším. Byla to lekce z vysoké pedagogiky - nikdy jsem si pak už nedovolil přijít na zkoušku nepřipravený. 
Vzpomínka druhá - společenská. Na fakultě, rusistiku nevyjímaje, se žilo družně. Mnohokrát jsem byl zaujatým a vděčným svědkem páně profesorova vyprávění, vzpomínek a anekdot ze života známých i méně známých osobností z brněnského akademického prostředí. Stanislav Žaža byl nejen znamenitým vypravěčem s nesporným hereckým talentem a sympatickým smyslem pro roztomile potouchlý humor, ale také skvělým imitátorem. Jeho schopnost ovládnout zcela přirozeným a nevtíravým způsobem komunikační prostor svými parodickými výstupy při neformálních společenských př́ležitostech byla pověstná, a například se značnou dávkou komické nadsázky mnohokrát, ale vždy se stejným úspěchem reprízovaná a půvabnou archaizovanou češtinou interpretovaná historka o tom, jak profesor Havránek zahnal gestapo, se do paměti jistě nejen autora těchto řádků vryla nesmazatelným způsobem.

Vzpomínka třetí - profesní. Tato vzpomínka je zprostředkovaná, nicméně pro osobnost zesnulého charakteristická. Začátkem 80. let byl Stanislav Žaža také akademickým funkcionářem, jako proděkan FF UJEP v Brně měl na starost studijní oblast. Ačkoliv nejrůznější záležitosti a problémy studentů řešil velmi zodpovědně a s jemu vlastním hypertrofovaným sociálním cítěním, podle očitých svědků se nezř́́dka stávalo, že jeho profesní zaujatost a pedagogická důslednost dočasně vzaly vrch nad jeho př́slovečnou shovívavostí. $V$ takových prŕpadech údajně nejprve se zachmuřeným čelem a staženými koutky červenou tužkou opravil všechny pravopisné a gramatické prohřešky v neštastníkově žádosti, a teprve pak se na text znovu podíval proděkanskými očima a rozladěně pronesl: „A co že to ten hoch vlastně chce...?"

Vzpomínka čtvrtá a poslední. Bydleli jsme nedaleko od sebe a vosledních letech, kdy už mu zdraví nedovolovalo docházet na fakultu, jsem pana profesora s jeho milou paní několikrát do roka navštěvoval. Pro všechny zúčastněné to byl vždy malý svátek a výjimečný zážitek, kdy se nejen vzpomínalo: pan profesor se stále živě zajímal o novinky na fakultě a na slavistice, kde strávil celý svůj profesní život. Při mém líčení nejrůznějších úkolů a obtíží, které musíme na pracovišti neustále řešit a překonávat, dostávala jeho tvář občas ustaraný a rozmrzelý výraz a obvykle následovalo upřímné omluvné postesknutí nad tím, že nemůže být svému už bývalému pracovišti víc nápomocný a užitečný, což do konce života těžce nesl a vnímal téměř jako osobní selhání. Vnitřně vlastně nikdy do důchodu neodešel. I když poslední rok života strávil prakticky na pojízdném křesle, stále podle svých ubývajících sil a možností pracoval. Jako poslední úkol si předsevzal napsat medailon $\mathrm{k}$ životnímu jubileu autora těchto řádků, který neskromně a spíše jako pandán $\mathrm{k}$ této vzpomínce otiskujeme na jiném místě tohoto dvojčísla. Díky, pane profesore.

Profesor Stanislav Žaža opustil tento svět stejně jak na něm žil - tiše, pokorně, jakoby se snahou nebýt nikomu na obtíž, a osobně jsem přesvědčen, že i s jakýmsi iracionálním pocitem osobní odpovědnosti a viny za to, že nestihl udělat nebo dokončit vše, co pro svůj obor, pracoviště i své nejbližší udělat mohl a měl. Přestože pro jeho 
nejbližší okolí nebyl jeho zhoršující se zdravotní stav tajemstvím, všechny, kteří pana profesora znali osobně, tato smutná zpráva bolestně zasáhla. $Z$ četných neformálních projevů soustrasti, které různými cestami přicházely na jeho mateřské pracoviště, bylo zřejmé, že mnozí vnímají tento smutný fakt jako skutečnou osobní ztrátu. Jako uvědomění si zraňující skutečnosti, že přišli o další možná dosud plně neuvědomovaný, ale pro pocit sounáležitosti se světem lidí nesmírně důležitý pocit vnitřní spř́ízněnosti s dobrým, laskavým, chápajícím a soucitným člověkem. Lidský profil osobnosti Stanislava Žaži představoval všechno to, čeho se nám nejen $\mathrm{v}$ akademickém prostředí stále více nedostává: nesobeckost, obětavost, kolegiálnost, přátelskost, skromnost, pokoru, lidskost.

Vážený a milý pane profesore, budeme na Vás vždy s úctou, láskou a vděčností vzpomínat.

fiři Gazda

https://doi.org/10.5817/OS2018-4-5

\section{Vzpomínka ryze osobní}

Nevím, zda je vhodné publikovat $\mathrm{v}$ odborném časopise žánr vzpomínky, proto nechám zcela na redakci, zda tento prríspěvek otiskne. Navíc má tento žánr jedno úskalí: nevyhne se tomu, aby kromě toho nebo těch, na něž se vzpomíná, nezahrnul i vzpomínajícího, takže pak se může stát, že čtenář má dojem určité nepatřičnosti. I s tímto vědomím však píšu následující ráádky.

Rok 2018 zůstane v dějinách naší rusistiky rokem, kdy ji navždy opustili její dva přední představitelé, pan profesor Stanislav Žaža a pan docent Václav Huňáček. Jejich odborný př́nos oboru bude určitě zhodnocen někým povolanějším. Já za sebe na ně chci vzpomenout jako na své nikoli učitele - věkový rozdíl mezi námi nebyl tak velký ale vážené kolegy, kterým jsem se ze srdce obdivovala, kteří byli mým vzorem, kteří po smutném odchodu mého pana profesora Vladimíra Barneta mi ze staré generace „zůstali“ na dvou rusistických katedrách, ke kterým jsem měla nejblíž i duchovně, i vzdáleností (protože jsem sice 41 let působila na UJEP v Ústí nad Labem, ale celý život jsem žila v Havličkově Brodě, ležícím na spojnici mezi Prahou a Brnem - pro spravedlnost musím však ještě dodat, že jsem duchovně měla blízko i k dalšímu významnému rusistickému pracovišti na FF UP v Olomouci.)

Prof. PhDr. Stanislav Žaža, CSc. se narodil 14. dubna 1929 a zemřel 5. srpna 2018 ve věku 89 let. Jeho oborem byla latina-ruština, profiloval se jako lingvista par excellence. Působil na Masarykově univerzitě v Brně. Já jsem ho znala z jeho publikační činnosti, ale především $\mathrm{z}$ různých konferencí a hlavně jako oponenta desítek rigorózních 